\title{
THE MAGIC OF THE MEZUZAH IN RABBINIC LITERATURE
}

\author{
Eva-Maria Jansson
}

Lund

The notion that the mezuzah - the capsule containing a parchment strip on which is written Deut. 6:4-9 and 11:13-21 and which is attached to the doorposts of a Jewish home - is protective has been explained in different ways. Two different developments have been suggested: either the mezuzah was originally an amulet, which the Rabbis sought to theologize, or it was a religious object which fell victim to popular superstitious notions ${ }^{1}$. In this paper, where the study is delimited to the Talmudic and some Geonic material, I intend to propose another explanation to the origin and development of the idea of its protectiveness.

The origin of the mezuzah as an object is obscure. The oldest references we have to it, e.g. in the Mishnah and the Tosefta, presuppose that it is an object on par with other religious objects, and that the affixing of the mezuzah is a mitsvah. To conclude that traditions found in later texts, regarding it as an amulet, are pre-Rabbinic and preserved unaffected by the Rabbinic mediation, is problematic. Discerning a popular influence, that is, a popular strata in the Talmudim, the She'iltot, Sefer Halakhot Gedolot and the Hekhalot literature, opposed to the views of the Rabbinic elite, is also difficult ${ }^{2}$.

The statements in the Talmudim relating to the mezuzah can roughly be divided in two groups. The first one contains the statements concerning the physical execution of the mitsvah, what one might call the stechnicalities «: what kind of leather to use, what ink to use, the layout of the text on the parchment, how to roll this etc. The other group of passages contains statements about the mitsvat mezuzah ${ }^{3}$, and this group is the primary focus of my investigation ${ }^{4}$.

* This paper was originally presented at the 5th European Congress for Jewish Studies, Copenhagen, 14-18 August, 1994.

1 For the former view, see Joshua Trachtenberg, in his Jewish Magic and Superstition: - A study in Folk Religion, which appeared in 1939. For the latter, see Martin Gordon: "Mezuzah: Protective Amulet or Religious Symbol?« Tradition: A journal of Orthodox Jewish Thought, Vol. 16, \#4, 1977, pp. 7-40; and Yehuda Lichtenstein, "הזמזוזה כסגולה לשמירת הבית, Tachumin, vol. 10, 5749, pp. 416-427.

2 The on-going debate on the relative age of the different types of early Rabbinic literature can unfortunately not be summarized in the context of this paper. The theories of a dichotymy between the learned elite and the illiterate masses have mostly been developed on material from medieval Christian Europe (e.g. Gurevich 1988). Applying them on other eras and cultures should be done with caution.

3 This group also contains the passages that reveal attitudes towards the mezuzah, like the definition in B. Ber. 47a of an 'am ha-aretz as someone who lacks a mezuzah on his door. Another example is the statement, that the gentleness of the reed merited it to be used when writing mezuzot (B. Taan. 20b). (Unless otherwise stated, the English translations of Biblical passages are taken from the JPS Tanakh, and of passages from the Babylonian Talmud from the Soncino translation.)

4 As will be seen, this is a qualified truth; in the material from post-Talmudic times, the physical features of the mezuzah will be also be discussed. 
Here are found statements that specify the rewards and punishments in connection with the mezuzah. The thought of reward and punishment in connection with mitsvot is found throughout the Talmud, both as a general assumption and as specified statements in connection with specific commandments ${ }^{5}$.

Regarding the mezuzah, there are different kinds of rewards, as there are different kinds of punishments. In B. Shab. 23b, the person observant of the mitsvah is said to merit a beautiful dwelling, and in B. Pes. 113b, the one lacking a mezuzah at his door is among those banned by heaven; both rather general statements. There are however statements of a different kind, and they are, I believe, clues to an understanding of the apotropaic notion that is, the belief in the mezuzah as protective and avertive - and its place within the Rabbinic literature.

These passages are those where the connection is made between fulfilment or ignorance of the mitsvat mezuzah and life, expressed as longevity, or death. This connection is in some $\operatorname{cases}^{6}$ an interpretation of the juxtaposition of the verses Deut. $11: 20-21^{7}$ :

$s$ For a discussion of this, see Urbach 1979:436ff. In e.g. B. Shab. 33a-b, we find a lengthy list of different sins (e.g. disregard of commandments) and their punishments. The views on this kind of connections are however not unambiguous; the perhaps most famous statement to the opposite effect is found in M. Avot 4:2, in the words of Ben 'Azzai: שכר מצוה מצוה, and, in another version, in B. Chullin 142a: »There is no reward for the fulfilment of the precepts in this world«. As an explanation of this incongruity, Urbach seems to suggest that the expressions of a more mechanistic view might be didactic (1979:270, 437). He also discusses the contradiction elsewhere: "The emphasis given to the inner worth of the precepts restricted, in no small measure, the concept of reward as the criterion of the appraisal of the precepts, but it did not entirely nullify the need to stress the idea of reward for the precepts - not only in the world to come, but also in this world - in exhortations to observe the commandments. Not all acepted the view of Ben 'Azzai [...], nor was eveyone prepared to be content with 'The reward of a precept is another precept' or to agree with the opinion of $R$. Jacob that 'There is no reward for precepts in this world.' $R$. Nathan taught: 'There is not a single precept whose reward is not given in this world; as to the world to come, I have no conception how great the reward is there.' But even R. Nathan equated the commandments from the viewpoint of their reward, much as Rabbi taught in the Mishnah (Avot ii,1): 'And be heedful of a light precept as of a weighty one, for you know not the reward given for the precepts' (Urbach 1979:349). He concludes his discussion: "However, it was just this comparison of the precepts from the aspect of their reward that did not prevent the Amoraim from promising the reward of longevity for commandments whose observance was lax, like phylacteries, for example: 'Resh Laqish said, He who puts on phylacteries live long' (Urbach 1979:350f). Neusner, on this question, flatly states: $\gg$ The reward of studying and living up to the lessons of Torah was both this-worldly and other-worldly« (1969:309).

6 B Kidd. 34a, B. Shab. 32b, Kallah 51a.

7 The awareness of this text within Rabbinic Judaism can hardly be over-estimated; being part of the Shema' it has a centrality that few other Biblical passages surpass. Admittedly, Deut. 11:21 is seen as the result of fulfilment of other parts of the passage Deut 11:18-20. In B. Shab. 32b, negligence of study of Torah is punished by the death of children, as an interpretation of these verses. The interpretation of vv. 20 and 21 reappear together in later Rabbinic literature, e.g. in the writings of R. Meir of Rothenburg where it is explicitly stated that the reward of the mitsvah of mezuzah is to be understood from the verse למצן ירבו, i.e. Deut. 11:21 (מאיר בן ברוך מרוטנבורג תשובות ...61). 


\section{וכתבתם על מזוזות ביתך ובשעריך

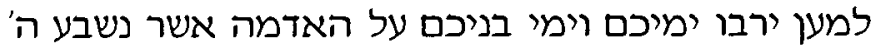 לאבתיכם לתת להם כימי ימי השמים עי על הארץ האי המה}

and inscribe them on the doorposts of your house and on your gates to the end that you and your children may endure in the land that the LORD swore to your fathers to assign to them, as long as there is a heaven over the earth.

The Talmudic interpretations of this passage, where the former verse is seen as conditional to the latter indicate that death may be a result of the neglect of mitsvot, among them the mitsvat mezuzah. Other Talmudic passages show that the thought of a connection between the fulfilment of mitsvot and specific events was not foreign to the Talmudic tradition ${ }^{8}$. Such a connection can also be seen within a greater frame-work: the perception of the realization of Torah in practical life through the enactment of the mitsvot as life bringing and the negligence thereof as lethal ${ }^{9}$.

Another reward for fulfilling the mitsvat mezuzah is protection, something that can be seen as a prerequisite for life - and a countermeasure to death. As an example can be mentioned an aggadic passage of some length, found in B. $A Z 11 \mathrm{a}$. There we are told how Onkelos the proselyte is chased by the Emperor. Onkelos escapes through converting three successive contingents of soldiers who caught him by pointing out the virtues of Judaism. The third group is shown a mezuzah and told the following: "According to universal custom, the mortal king dwells within, and his servants keep guard on him without, but [in the case of] the Holy One, blessed be $\mathrm{He}$, it is His servants who dwell within whilst $\mathrm{He}$ keeps guard on them from without; as it is said: The Lord shall guard thy going out and thy coming in from this time forth and for evermore (Ps. 121:8)

This parable, where God is contrasted to a mortal king, is also found in B. Men. 33b. There it is attributed to R. Hanina as an addition to a statement, that the reason why the mezuzah is to be fastened at the outer part of the door-post is that the whole house should be protected ${ }^{10}$.

According to my opinion, there is no doubt that the story about Onkelos is intended to be understood as dealing with physical protection, given through the mezuzah. ${ }^{11}$ Since

8 For discussion and further references, see Urbach 1979:436ff.

9 There are passages in the TB where Torah is referred to almost as a remedy: e.g. B. Eruv. 54a: "R. Joshua $b$. Levi stated: [...] If he feels pain in his head, let him engage in the study of the Torah, since it is said, For they shall be a chaplet of grace unto thy head (Prov 1:9), ..« A more general statement is found in B. Yoma 72b: R. Joshua b. Levi said: "What is the meaning of the Scriptural verse: And this is the law which Moses set [before the children of Israel] (Deut 4:44)? - if he is meritorious it becomes for him a medicine of life, if not, a deadly poison. That is what Raba [meant when he] said: If he uses it the right way it is a medicine of life unto him; he who does not use it the right way, it is a deadly poison $\%$.

10 What the protection is supposed to be against is not explained in the Talmudic text; Rashi identifies the threat as maziqim, i.e. evil spirits.

1 Cmp. Gordon 1977:14. 
protection is a prerequisite of life, I include the texts giving protection as a reward, in the group stating the reward of the mitsvah as life or longevity. Life and death are, after all, two sides to the same coin, in that the one is the absence of the other ${ }^{12}$.

Our next question must be: protection against what? Death is of course the ultimate threat; and the most general cause of death and the most constant threat in human experience has always been diseases of different kinds.

Diseases were considered to be results of demonic assaults ${ }^{13}$ and to guard oneself against these was a main concern. Further evidence of this belief can be found in archaeological material from this period, namely amulets of different kinds ${ }^{14}$. In the Talmudim, the use of amulets is not a question of controversy as long as they are approved amulets $^{15}$ - otherwise they are sorcery and among the ways of the Amorites ${ }^{16}$.

Thus, when the Talmudic literature states that the mezuzah gives protection or prolongs the life of the person fulfilling the mitsvah, this also implies that it counteracts

12 This relation has been described as »the symmetry condition « in an article by Asa Kasher and Shlomo Bidermann dealing with reward and punishment (Kasher \& Bidermann 1984:435): „The religious concept of reward is the inverse of that of punishment. The negation of one should with the appropriate modifications, yield the other."

13 Urbach 1979:99ff, 165; Montgomery 1913:89ff; Blau (1898:55): »Wie wir schon früher gesehen haben, wurden die meisten Krankheiten den bösen Geistern zugeschrieben, der Kranke galt als besessen oder bezaubert.*

14 Montgomery 1913, Naveh \& Shaked 1985 (on mostly Palestinian material).

15 The Babylonian Talmud are ambigous on what constitues an accepted amulet. On the one hand, amulets can only be protective, not healing (B. Shab. 15b), on the other, an approved amulet is one that has healed three times (B. Shab. 61a) and it is also said, that whatever is used as a remedy is accepted (B. Shab. 67a).

16 B. Shab. 15b. Cnf. Urbach 1979:130; Cohen 1957:267ff, 294. It is evident that Urbach wants to see the evidences of »magic« in the Rabbinic literature as an influence from and reaction on popular beliefs. He writes on magic: "In actuality, even the Sages of the Talmud and Midrash - despite their fundamental recognition that there is none besides God and that consequently witchcraft does not exist - could not ignore the facts, to wit, that broad masses of the people believed in and made use of these practises." (1979:101) The same is visible in his treatment of the practices in connection with "The Power of the Divine name (pp. 124-134, esp. p.130). However, he is also forced to admit: »We know that even Sages, especially in Babylon, used remedies that were obviously of a magical character" (1979:101). I find that any dichotomy between religion and magic hard to take into consideration regarding the Talmudic material. Apart from the fact that this supposed dichotomy is called in question in the scholarly debate, the establishing of it within the Talmudic material presupposes an objective definition, something I would rather be excused from establishing. Naveh \& Shaked describes the situation aptly: "Can any doubt be raised as to the orthodoxy, in terms of Jewish religion, of the people who wrote and used these amulets? Contemporary Jewish sources, notably the Talmudic and Midrashic literature, are notoriously ambiguous about magic. It must be recalled that we should not take the utterances of the sages in the matter of magic at face value. Magic is officially condemned, but many people who practised what we call 'magic' would deny that they indulged in a practice which was against Jewish law. They would say that they practised healing, protection, etc., and that they relied not on magical powers, but on the power of God and His angels. The argument about the legitimacy of magic, among Jews just as in other cultures, sometimes revolves around the definitions of terms.« (Naveh \& Shaked 1985:36). 
demonic assaults, the cause of sickness and ultimate death, and other misfortunes. And so, the outcome is supposed to be the same as through the use of an amulet:

In the She'iltot by R. Achai Gaon of Babylon, a work composed in the mid-eigth century, is quoted a story found also in Talmud Yerushalmi (Peah 15d). The version in the Yerushalmi tells of the exchange of gifts between R. Jehudah ha-Nasi' and the Parthian king Artaban ${ }^{17}$ :

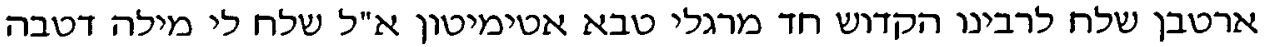

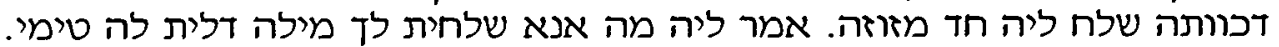

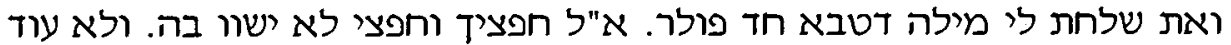

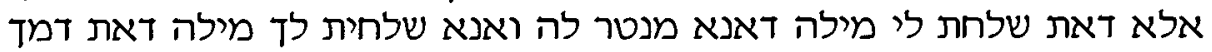

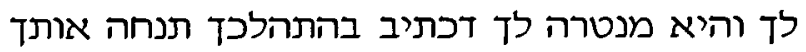

Artaban sent to our Holy Rabbi an invaluable pearl. He said to him: Give me something of comparable value. He sent him a mezuzah. He said to him: What I sent to you was something that is invaluable. But you sent me something worth one folar. He answered him: Your valuable and my valuable can not be compared to $\mathrm{it}^{18}$. And not only that, but you sent me an object that I have to protect, but I sent you an object that protects you when you sleep, as it is written: »When you walk, it will lead you (Prov. 6:22) ${ }^{19}$.

In She'iltot ( $\$ 153)$ however, the story reads as follows ${ }^{20}$ :

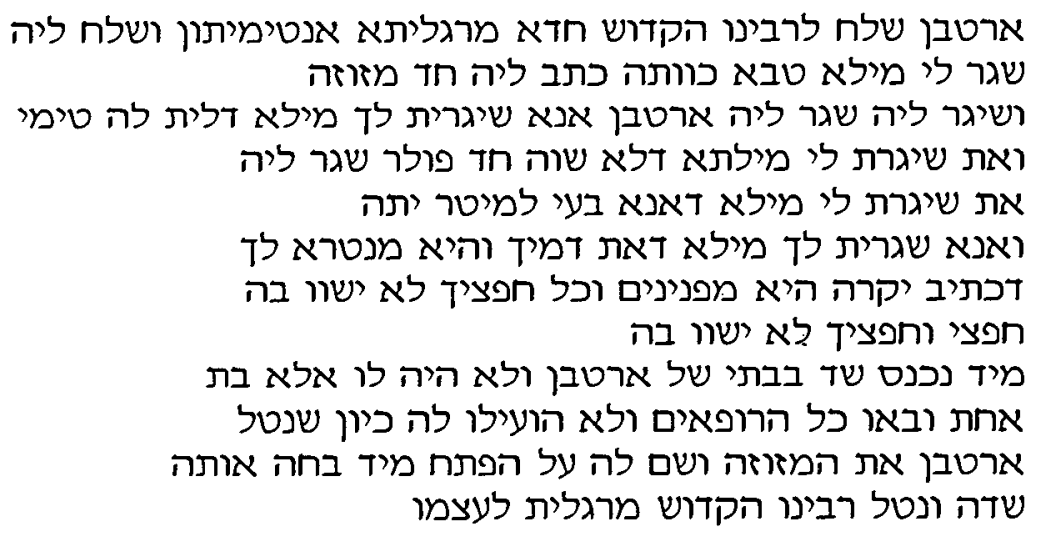

17 In some MSS to Bereshit Rabbah (35:3) the story is also found in a version almost identical to the Yerushalmi-version. The exact relationship between these texts is for the present discussion of less importance.

18 This might be a possible allusion to Prov. 3:15. See further the text in the She'iltot below.

19 The whole verse runs: When you walk it will lead you, when you lie down it will protect you, and when you are awake it will talk with you.

20 She'iltot ..., ed. Mirski, 1977:18; Engl. transl. E-MJ. 
Artaban sent to our Holy Rabbi an invaluable pearl together with the message: Send me something as good. He wrote him a mezuzah and sent to him. Artaban sent him (word) and said: I sent you something priceless, and you send me something that is not worth a folar. He sent him (an answer): You sent me something that I have to guard, and I sent you something that protects you when you sleep, as it is written "She is more precious than rubies, and all the things you can desire are not to be compared unto her (Prov. 3:15)«, your thing and my thing can not be compared to her. Immediately entered a demon into the daughter of Artaban and this was his only daughter and all the physicians came and they could do nothing for her, (but) as soon as Artaban took the mezuzah and attached it to the door fled the demon from her at once and our Holy Rabbi kept the pearl to himself.

The relationship between the She'iltot and the Yerushalmi has been subjected to some debate. There is no consensus whether the work was written before or after R. Achai moved to the Land of Israel ${ }^{21}$. Did R. Achai know of, and quote from, the Yerushalmi ${ }^{22}$, or does the shared material originate from a common (oral) tradition ${ }^{23}$, or are the passages that seem to be quotations later interpolations ${ }^{24}$ ? Apart from the fact that the whole she'ilta 153, where the story is found, deals with halakhot pertaining to mezuzot and other scrolls, there is no apparent clue in the context why the story about Artaban should have

2I The possible historical background of the story and its veracity has been debated; see e.g. Neusner 1965:82-88 and Dinari 1978:87-92.

22 Itzchaki (1991) maintains that the quotes were made to gain authority for the work of the Babylonian scholar in Eretz Israel, where Itzchaki claims that the work was composed.

23 Ginzberg 1909:82f. Ginzburg suggests that »Rabbi Aha drew his Haggadot from sources other than the Yerushalmi, there can be no doubt that the legend which he relates about Artaban and Rabbi, CXLV, 114, is not taken from the Yerushalmi Peah, I, 15d, bottom, but from a Haggadic source, and a babylonian Haggadic source at that.« The reasons he gives are two. שדה is according to him a wholly Babylonian word - »The Palestinians knew no female demons, and certainly not the word applied to them by Rabbi Aha«. But the demon entering the daughter of Artaban is a ש - a male demon! On this point the text in unambigous. Maybe the masculine and feminine forms were interchangeable, or the difference ifs the result of a miswriting. Ginzberg's second argument is the similarity to a story given in an abridged version in B. Meilah $17 \mathrm{~b}$ (with a more elaborate version in Sefer Halakhot Gedolot, Pereq $M e^{\prime} i l a h$ ), where R. Shimon b. Yochai cures a Roman princess, into whom a demon has entered. There is however an important difference. In the story about $R$. Shimon, the entering and departing from the princess by the demon is part of a deal between the demon and the Rabbi, in order to ensure a "miracle « that will influence the Emperor to lift a ban from the Jews. No such deal is hinted at in She'iltot. This difference is in my opinion enough to question any close relationship between the two stories. (The reference »CXLV,114 « refers to Naftali Z. Y.Berlin's edition of the She'iltot from 1861-67.).

24 For further references and discussion of these passages, see e.g. Ginzberg 1909:78-86, Itzchaki 1991. For a discussion of all the theories, see Brody 1991:XII, who supports the interpolation theory. The »common source-theory « would seem to be supported by the parallel version in Bereshit Rabbah, but then the common source would have to be Palestinian. 
been interpolated. I would, however, like to focus on three other questions in connection with the stories ${ }^{25}$ :

First, is the protection promised physical?

The story about Rabbi and Artaban in the Yerushalmi, is quoted as part of a discussion on M. Peah 1:1:

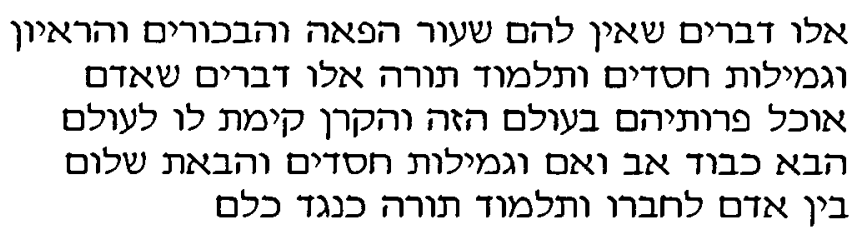

These are things which have no measure: peah, first-fruits, appearance [in the Temple], rendering kindness, and studying Torah.

These things are such that a person eats their fruits in This World but the principal remains for him in the World to Come: honoring father and mother, rendering kindness and bringing peace between a man and his fellow; and Torah study matches them all $^{26}$.

Thus, that there can be reward for mitsvot in this world is stated already in the Mishnah; and the story about Artaban can be seen as an illustration in order to emphasize this. The nature of the protection is shown through the pearl: being a valuable object, it needs to be physically protected. As for the story in the She'iltot, there is, in my opinion, no question that the matter is physical protection, the threat being the demon.

Secondly, why is Rabbi portrayed as giving a mezuzah to a heathen $\mathrm{king}^{27}$, promising physical protection?

Some suggestions have been made in answer to this, e.g. that Artaban was not a heathen king but a wealthy Jew who was given a lesson on the relative value of pearls by $\mathrm{Rabbi}^{28}$, or that Artaban, a heathen king, was given a lesson on the value of Torah ${ }^{29}$. It

25 The difference in Biblical quotation (Prov. 6:22 vs. 3:15) is puzzling. A clue might be found in the passage preceeding the story in the Yerushalmi, where Prov. 3:15 is expounded as referring to the words of Torah. This might indicate that $\mathrm{R}$. Achai indeed was quoting the Yerushalmi, and for some reason felt that this verse was more adequate than Prov. 6:22.

26 Translation taken from Peah. The Artscroll Mishnah Series ...

27 The deliviery of a mezuzah to a non-Jew has been a puzzle to later commentators. As indicated by prohibitions of leaving a mezuzah at a Gentile house, cnf. e.g. B. BM 102a, Y. Meg. 75c, it seems that it was not allowed to give a mezuzah to a Gentile. In Geonic times this was explicitly stated; for references, see Lichtenstein 1989:424. To decide whether the prohibition was in force earlier calls for further study.

Dinari 1978:91, 100.

29 Gordon 1977:13f. As far as I understand, this explanation requires that Artaban knew that Prov. 6:22 refers to "your father's commandments and your mother's teaching " and Prov. 3:15 to Wisdom; if so, this would indicate that Artaban was a Jew, since he can hardly have been encouraged to keep his hereditary religion as a lesson on the value of Torah. 
seems strange, however, that the story would have been transmitted and quoted in its present form, if the intention was not to portray a communication between Rabbi and a heathen king. I suggest that, regarding the actors, we accept the story as it is. Regarding the message, physical protection is the matter.

Finally, why is the part about the demon found in the version in the She'iltot?

In Geonic times, the connection death/sickness and demons remained, as can be seen from e.g. the amuletic material found in the Cairo Geniza ${ }^{30}$. Thus, the appearance of a demon in connection with an object connected with life and death is in no way surprising. The reward for mitsvot is life - the threats against life are demonic. The absence of the demon in the Yerushalmi might be explained by the assumed difference between Babylon and the Land of Israel when it comes to demons. It has been argued that the Babylonian scholars were much more ready to accept the existence of demons and other spiritual beings than their colleagues in the Palestinian academies ${ }^{31}$. Accepting this, the absence of the demon in the Yerushalmi version might be a manifestation of this difference ${ }^{32}$. As for the She'iltot, its goal was according to some scholars didactic ${ }^{33}$; if so, its version of the story might be seen as a way to emphasize the life-bringing quality of the mitsvot.

That the mezuzah was seen as connected to life and death, the latter a possible result of demonic activity, seems to be supported by the additions - in this context anything else than the two Biblical passages normally included in the mezuzah ${ }^{34}$ - that were made to the mezuzah from the Geonic period and onwards.

In one of the versions of Sefer Halakhot Gedolot, the halakhic code of the 8th or 9th century and of uncertain authorship, one is enjoined - without any further reasoning - to write "a shin with its tagin " on the backside of the parchment, so that it is visible through the hole that shall be prepared in the capsule where the mezuzah is put ${ }^{35}$. The relationship

30 Schiffman \& Swartz 1992:35: »In the magical material from the Genizah, demons are seen primarily as causes of disease. Both in those amulets which are written specifically for healing or protection from disease [...], and in those intended to guard against other injuries, the demons are agents of bodily harm.«

31 Ginzberg 1941:xxxiv-xxxvi, who labels this »the chief difference between the two Talmuds in the field of theology«.

32 This is independent of whether the original story included the demon or not.

33 Brody 1991:XVII suggsts that the she'iltot was »homiletical-pedagogical vehicles aimed primarily at a popular audience . This suggests a view of the text as »popular«, an approach to the Rabbinic material that I have rejected above. For additional discussions on the didactic aim of She'iltot, see Itzchaki 1991:132. It was suggested by Prof. Yaakov Elman, at the 5th EAJS Congress, Copenhagen 1994, that the occurance of this story in the She iltot might be explained in connection with the practice of using amulet bowls: Achai felt that it was better that the people did the mitsvah for the wrong reason than continued with the use of the bowls. In order to judge this theory, an analysis of all the statements about the mitsvot, their reward and punishment and other traditions connected to them in the She'iltot would have to be done, a task that is beyond the scope of this paper.

34 The antiquity of two passages in the mezuzah is witnessed by M. Men. 3:7: "The two parashiyot in the mezuzah validates one another, and even one letter is essential to them."

35 Sefer Halakhot Gedolot ..., ed. Hildesheimer, 1971:499-501. This edition is based on the Milano MS, dated 1469, but nevertheless deemed by Hildesheimer to be the most reliable (Hildesheimer 1971:15). 
of this to the writing of Shaddai, the Divine name most commonly connected with the mezuzah and one to which we shall return, is yet to be explained ${ }^{36}$. Additions were, however, made also on the inside. In the same chapter of Halakhot Gedolot, a whole »recipe« is given for the writing of a mezuzah with added names of angels, signs etc, with the following result ${ }^{37}$ :

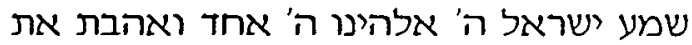

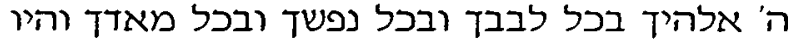

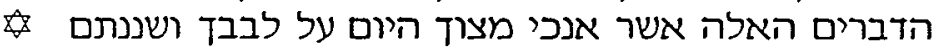

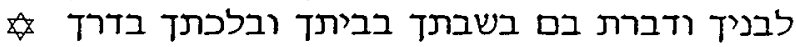

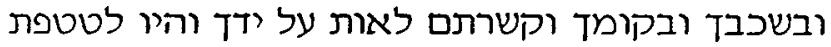
בין עיניך וכתבתם על מזוזת ביתך ובשית עשריד

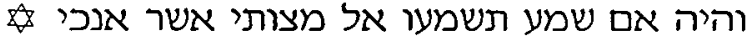

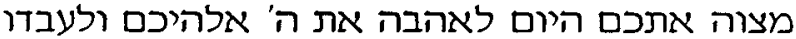

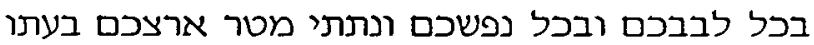

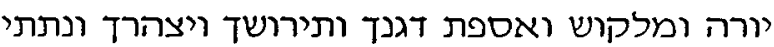

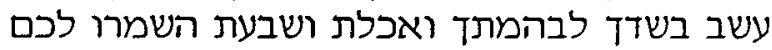

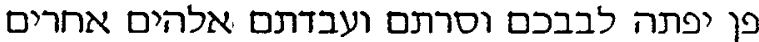

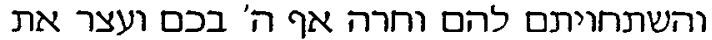
השמים ולא יהיה מטר והאדמה לא תחת נתן את יבת יבולה

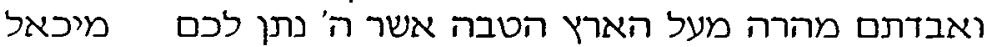

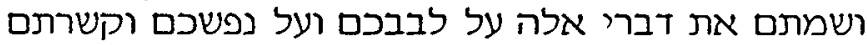

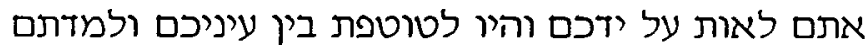

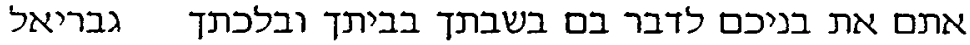
בדרך ובשכבך ובקומך וכתבתם בתם על מזוזות ביתך

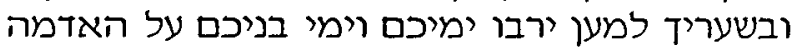
אשר נשבע ה' לאבתיכם לתת להם כימי השמים הכיכי המימה על הארץ

$$
\$
$$

Angelic names were used in amulets, of this we have ample proof from late Talmudic and early Geonic times, e.g. the so-called "incantations bowls«. If we assume that these names were not a matter of decoration when used in mezuzot, they must have had a function. With the theory sketched above, that the apotropaic notion can be explained through the thought of reward and punishment as connected with the mitsvot, the additions of angelic names to the mezuzah can be explained. Angels are the counterparts of demons, the administrators of diseases and ultimate death ${ }^{38}$. Especially an angel as Rafael can be

36 Hildesheimer (1971:500, note 5) refers on this matter to $\S 961$ in the Mordecai (Halakhot Ketannot), who mentions the custom of writing 1 ש on the back of the mezuzah. Cnf. also $\S 960$ of the same work, where other additions are mentioned. Since there are some obscurity on the authorship of these passages of the Mordecai, their relevance as witnesses to the Sefer Halakhot Gedolot is uncertain.

37 Stars of David added in accordance with Hildersheimers description of the MS in note 6, p. 501.

38 A possible problematic figure here would be the Angel of Death $\%$. However, being closely related to the demonic forces, I choose to count him among them, despite his epithet; probably מלאך is more to be taken as "messenger*. Cnf. Noy 1972:952ff. 
supposed to be effective in this context. The use of angelic names is even less surprising when we remember the Talmudic traditions about protective angels ${ }^{39}$.

Also other names were added. In Hekhalot Zutrati, a work first mentioned in the beginning of the eleventh century but containing older material of both Palestinian and Babylonian origins ${ }^{40}$, the following is stated in $\S 513$, without any further explanation or motivation $^{41}$ :

\author{
וזהו השם בן עשרה וארבע אותיות. והוא שאחורורי

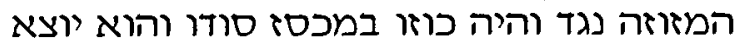

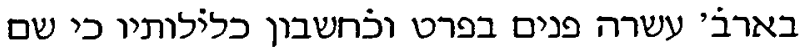 \\ ה' אקרא הבו גודל אלה פנים ברינו
}

This is the name of fourteen letters. This is the one on the back of the mezuzah, opposite כוזו במכסז סודו :והיה. It appears in fourteen ways, separate and according to the calculation of its entirety: »the name of the Lord will I call, bring greatness to our God (Deut. 32:3) ${ }^{42}$.

Divine names, to which the fourteen-letter name - here in what seems to be a corrupt form - must be counted, is something otherwise well known from amulets from Talmudic times and onwards. This passage seems however to be the first mention ever of any addition of a Divine Name to the mezuzah ${ }^{43}$.

39 For references, see Urbach 1979:138-146, 159-161. The connection between protection of the house and the mezuzah is also stated clearly in Sefer Halakhot Gedolot, when it is said: «the house on which there is fastened a mezuzah is protected by the Holy One, blessed be He«, whereupon follows the parable mentioned above attributed to R. Hanina where God is contrasted to a mortal king, in that $\mathrm{He}$ protects his people and not the other way around (Sefer Halakhot Gedolot...: 499). This passage is found in all three MSS mentioned.

40 Schäfer 1989:XVI-XVII. Gruenwald $(1980: 142,149)$ suggests an origin in the 2nd-3rd centuries.

41 Hebrew text taken from Schäfer 1981.

42 Transl E-MJ. This translation differs from the translation given in Übersetzung der Hekhalot-Literatur III $\$ \$ 335-597$ (ed. Schäfer), where one of the words (7ג) in the Hebrew text istranslated twice: »Er ist es, der auf der Rückseite der Mezuza [steht], gegenüber: NGD WHYH KWZW BMKSZ SWDW « (my emphasis) and NGD WHYH is understood as the first part of the name (1989:232f). On the basis of later use of the fourteen-name letter on mezuzot (e.g. in Machzor Vitry) the conclusion must be that NGD WHYH is not part of the name, as seems to be the opinion of the translator (see note 1 to the passage in question), but an instruction where to write the fourteen- (though here reduced to thirteen-) letter name: at the place on the backside of the parchment corresponding to the place on the front where the beginning of the second passage in the mezuzah is written: "... (Deut 11:13).

43 The MS is dated c. 1400 , and thought to originate from Germany, possibly German Chassidic circles (Schäfer 1981:IX). Hermann (1988:79f) discusses the passage in the following words: »Welche Rolle spielt der Geheimname uzuf in der Hekhalot-Literatur? In der Synopse zur Hekhalot-Literatur findet sich der einzige Beleg im Sondergut der New Yorker Handschrift N8128 (\$513): 'Dies is der 14buchstabige Name, der auf der Rückseite der Mezuza (steht) und lautet: כוזו במכסז סודו 'Das Kryptogram von Dtn. 6,4 weist zwei Korruptelen auf; zum einen ist das waw in במוכסז ausgefallen, und zum anderen wird das zweite סודר ('sein Mysterium') wiedergegeben. Offentsichtlich hat 
My proposal is thus that passages showing an apotropaic understanding of the mezuzah can be explained by the connection between this mitsvah and death as a punishment. The mezuzah was supposed to give the same »reward « as the amulets, i.e. protection against sickness - caused by demons - and ultimate death; the use of the same signs, and angelic or Divine Names, in the mezuzot as in the amulets was not such a giant - or illogical leap. This is, I propose, how the notion of the mezuzah as a life-bringing mitsvah led to additions of the type found in life bringing amulets.

The last question is: why is the mezuzah singled out as particularly life-bringing? As mentioned, longevity as reward and death as punishment were mentioned also in connection with other mitsvot. This might tentatively be explained by three factors. First of all, the Biblical verses cited above; taken literally, they state the connection between mezuzah and life quite openly. Secondly, there is the object in itself. Since ultimately Torah is the life-bringer and the mezuzah is a scroll containing words of Torah ("and you shall write these words on your doors and on your gates «), this combination might easily have led to the perception of it as a Torah scroll in miniature - a representative of the life-bringing $\mathrm{Torah}^{44}$. A third factor might be the place of the mezuzah : constantly at the door of the home- where any guard is normally put ${ }^{45}$.

Thus, I propose that the apotropaic notion of the mezuzah can be understood in the context of views on reward and punishment, as well as notions about demons as the causes of diseases and misfortunes of different kinds. Both these contexts were intrinsic parts of

der Schreiber der New Yorker Handschrift den Geheimnamen nicht mehr verstanden. Auf den apotropäischen Charakter der Mezuza im Kontext der Hekhalot-Texte wird ausdrücklich in $\$ 346$ (HZ; nur M22) und $\$ 673$ (MR) hingewiesen. Der Kontext von $\$ 513$ ist magischen Inhalts und besteht vor allem aus dem permutierten Gottesnamen, nomina barbara und Engelnamen, die teilweise auch in den übrigen Hekhalot-Texten belegt sind. " A few comments seem appropriate. I am not as convinced as Herrmann, that the $\$ \S 346 / 673$ shows that the mezuzah was seen as apotropaic: the passages refer to the "sign(s) on the doorpost(s) « and «the Destroyer - a combination which seems closer to the story of the Pesach in Egypt. Regarding the corruption of the name, Herrmann assumes that the reason was the scribe's unawareness of the meaning of the name. Prof. Moshe Bernstein of Yeshiva University suggested at the 5th EAJS Congress, Copenhagen 1994, that the reason was that the scribe did not want to spell out this Divine Name in its real form for everyone to read, so he put it in the MS in a corrupt form. Another possible explanation is that the scribe makes an interpretation and adds another quality to the name: mysteriousness - we know that the scribes and copyists in Medieval times often changed the MS they were working on (private communication Prof. Malachi Beit-Arié of the Jewish National and University Library, Jerusalem). The otherwise oldest reference of the practice of adding the fourteen-letter name is found in the Machzor Vitry, a halakhic work of the eleventh century attributed to R. Simchah of Vitry, a pupil of Rashi, where both the name Shaddai and the fourteen-letter name are mentioned (Machzor Vitry \$515). The fourteen-letter name seems, apart from this instance, to be unknown in Talmudic and Geonic times. It is not mentioned in the index of Montgomery's editions of the incantations bowl from Nippur, neither in Shaked \& Naveh's Amulets and Magic Bowls. Without saying anything definite about the relation between Hekhalot Zutrati and Machzor Vitry, it thus seems possible to state that the custom of writing the 14-letter name on the backside of the parchment was established at least at the end of the 10th century, probably earlier.

44 Admittedly, tefillin are also mentioned as e.g. effective against demons (e.g. B. Ber. 23a-23b) and as life-bringing e.g. (B. Men. 44a). The origins and development of these notions merits however a separate study.

45 The mezuzah also differs in that it is incumbent on everyone, not only on a certain group within the community, as e.g. the tefillin. 
Talmudic and Geonic Judaism and might also explain the additions made to the mezuzah from Geonic times onward, without the assumption of popular miscomprehensions, or amuletic origins of the object itself. 


\section{References}

Blau, Ludwig

1898 Das Altjüdische Zauberwesen. II. Auflage. Berlin: Verlag von Louis Lamm.

Brody, Robert

1991 The Textual History of the She'iltot. New York - Jerusalem: The American Academy for Jewish Research. (Hebr. \& Eng.)

Cohen, A.

1957 Everyman's Talmud. London: J. M. Dent \& Sons Ltd. et al.

Dinari, Yedidah

1978

דינרי, ידידיה מצוז

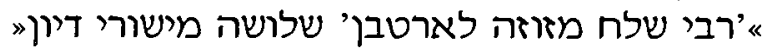

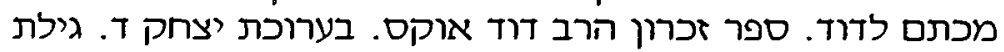

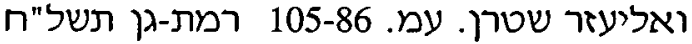

Ginzberg, Louis

1909 Geonica. I. The Geonim and Their Halakic Writings. Texts and Studies of the Jewish Theological Seminary of America vol. 1. New York: The Jewish Theological Seminary of America.

Ginzberg, Louis

1941 A Commentary on the Palestinian Talmud. A Study of the Development of the Halakah and Haggadah in Palestine and Babylonia. Vol. I New York: The Jewish Theological Seminary.

Gordon, Martin

1977 »Mezuzah: Protective Amulet or Religious Symbol?« Tradition: A Journal of Orthodox Jewish Thought, , Vol. 16, \#4, pp. 7-40.

Gruenwald, Ithamar

1980 Apocalyptic and Merkavah Mysticism. [Arbeiten zur Geschichte des Antiken Judemtums und des Urchristentums XIV] Leiden: E. J. Brill.

Gurevich, Aron

1988 Medieval popular culture: problems of belief and preception.

Cambridge: Cambridge University Press 
Hermann, Klaus

1988 "Die Gottesnamen מצפץ מוז in der Hekhalot-Literatur".

Frankfurter Judaistische Beiträge. Heft 16, pp. 75-87. Frankfurt am Main.

Itzchaki, Efraim

1991

יצחקי, אפרים

«על שימושו של בעל השאולתות בירושלמי Moreshet Yaakov. Yearbook of Teacher's Seminar 1991, pp. 128-132. Rehovot.

Kasher, Asa \& Bidermann, Shlomo

1984 "Religious Concepts of Punishment and Reward « Philosophy and phenomenological research, vol. 44, No. 4, pp. 433-451.

Lichtenstein, Yehuda

ליכנשטיין, יהודה

1989 תחחומין «המזוזה כסגולה לשמירת הבית, vol. 10 (5749), pp. 416-427.

Machzor Vitry

מחזור ויטרי - - - - מ

1923 Ed. S. H. Hurwitz. Nürnberg (repr. Jerusalem 1988).

Meir b. Barukh of Rothenburg מאיר בן ברוד [מהר"ם] מרוטבורג תשובות פסקים ומנהגים. אסף... מאת יצחק זאב כהנא חלק שני. ירושלים תש"ד ומנים

Montgomery, James A.

1913 Aramaic Incantations Texts from Nippur. Philadelphia: The University Museum.

Naveh, Joseph \& Shaked, Shaul

1985 Amulets and Magic Bowls. Aramaic Incantations of Late Antiquity. Leiden: E. J. Brill et al.

Neusner, Jacob

1965 A History of the Jews in Babylonia. Vol. I. The Parthian Period. Leiden: E. J. Brill.

Neusner, Jacob

1969 A History of the Jews in Babylonia. Vol. IV. The Age of Shapur II. Leiden: E. J. Brill.

Noy, Dov

1972 »Angel of Death« Encyclopaedia Judaica, vol. 2, cols. 952ff. Jerusalem: Keter Publ. House. 
1990 The Artscroll Mishnah Series: Peah. Translation ...: R. Mordecai Rabinovitch. Ed. R. Hilel Danziger. New York: ArtScroll.

Schiffman, Lawrence H.\& Swartz, Michael D.

1992 Hebrew and Aramaic Incantation Texts from the Cairo Genizah. Selected Texts from Talylor-Schechter Box K1. [Semitic Texts and Studies 1] Sheffield: Sheffield Academic Press.

Schäfer, Peter (Hrsg.)

1981 Synopse zur Hekhalot-Literatur . [Texte und Studien zum Antiken Judentum 2] Tübingen: Mohr (Siebeck).

Schäfer, Peter (Hrsg.)

1989 Übersetzung der Hekhalot-Literatur III $\S \S 335-597$. [Texte und Studien zum Antiken Judentum 22] Tübingen: Mohr (Siebeck).

Sefer Halakhot Gedolot

1971 ... ad fidem codicum editit. Prolegominis et notis instruxit Ezriel Hildesheimer. Tom. 1. Jerusalem: Mekize Nirdamim (Also with Hebr. title).

Sheil'tot de-Rav Achai Gaon 1977

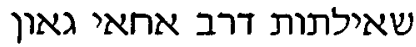
דברים. ביורים והערות אירות מאת שמוא שמאל קלמן מירסקי.

ירושלים

Sifre on Deuternomy

1986 Sifre. A Tannaitic Commentary on the Book of Deuteronomy. Translated from the Hebrew with Introduction and Notes by Reuven Hammer. [Yale Judaic Studies XXIV] New Haven and London: Yale University Press.

JPS Tanakh

1988 Tanakh. The Holy Scriptures. The New JPS Translation According to the Traditional Hebrew Text. Philadelphia 1988

Trachtenberg, Joshua

1939 Jewish Magic and Superstition: - A study in Folk Religion. (Repr.)

New York: Atheneum.

Urbach, Ephraim E.

1979 The Sages. Their Concepts and Beliefs. Vol. I-II. Jerusalem: The Magnes Press. 


\section{Summary}

Denna uppsats behandlar uppfattningen av mezuzan som ett föremål som avvärjer olyckor och andra negativa ting. Denna föreställning har förklarats på olika sätt: dels har man menat att mezuzan ursprungligen är en amulett, vilken rabbinerna sökt »teologisera«, dels att tankarna är ett exempel på vidskepelse knuten till ett religiöst föremål.

Uppsatsen diskuterar dessa förklaringar mot bakgrund av den talmudiska attityden till bl. a. amuletter. Syftet är att visa att de föreställningar som knutits till mezuzan måste diskuteras med hänsyn tagen till dess roll som mitsvah (bud), genom vilken den meriterar straff eller belöning beroende på dess uppfyllande. Med detta som utgångspunkt diskuteras avsnitt ur den rabbinska litteraturen från talmudisk och geonisk tid, t ex R. Achai Gaons She'iltot, Sefer Halakhot Gedolot och Hekhalot Zutrati.

Mot denna bakgrund kan också de $\mathrm{s} \mathrm{k}$ »magiska« tilläggen till mezuzan förklaras. Den avvärjande funktionen kan förstås inom den rabbinska judendomens ramar, utan antagande av en bakgrund för mezuzan som amulett eller som ett resultat av traditioner motställda den officiella synen. 